\title{
ECONOMIC DIPLOMACY FOR DEVELOPMENT PARTNERSHIP
}

\section{Rajendra Shrestha}

\begin{abstract}
The turn of events after the end of the Cold War called for revisiting traditional approaches to foreign policy. Shift in the world order triggered by enhanced economic activities in the national, regional and international markets has increased the need for coordinated economic diplomacy. Nepal, after the restoration of democracy in 1990, attempted to institutionalise and practise economic diplomacy through the Ministry of Foreign Affairs and its overseas missions. Exploring the leading features of economic diplomacy, this study revisits the economic diplomacy experiences of Nepal. Underscoring how a country's development success, in the globalised era, depends on the application of new skills and tactfulness in the conduct of relations by the lead ministry in the government, this paper internalises the importance of more competent and robust strategies to enhance the spirit of coordinated economic diplomacy. Hypothesising that Nepal has huge potential for development and economic growth, and prospects to conduct coordinated economic diplomacy, the study recommends strategies to strengthen coordinated economic diplomacy as a tool to advance Nepal's economic, political and strategic interests.
\end{abstract}

Keywords: Economic Diplomacy, Nepal, Strategies, State Actors, Non-state Actors

\section{Introduction}

Global politics underwent a paradigm shift after the end of World War II. As the world community witnessed increasing incompetence of state-centric economic models, economic prosperity through the participation of the private sector, international agreements and linkages gained widespread admiration (Booth, 2018). The rapid turn of events in the social, political and economic dimension led to a significant intellectual shift, away from the conventional approach to foreign policy. As a result, economic diplomacy came to the forefront in the late 1990s (Lee \& Hocking, 2010), which is the most important and popular

He specializes in the areas of sustainable economic development and diplomacy. He has published in international journals including a hand book on preventing noncommunicable diseases through diet, exercise and stress management. He has over 35 years of international development experience working with the WB, ADB, UNDP. 
aspect of conducting international relations in the $21^{\text {st }}$ century. Although economic diplomacy involves the use of economic resources and cooperation between states for mutual benefit, the US-China trade war, today, is the biggest geopolitical schism (Zirovcic 2016). Economic interdependence has become a double-edged sword where "conflict of logic in the commerce of grammar", as American political scientist Edward Luttwak described, will result in no winners (Kapustina, Lipková, Silin, \& Drevalev, 2020). Nonetheless, even when political relations between the two countries become acrimonious, economic diplomacy can play a significant role in neutralising the situation (Zirovcic 2016). Economic diplomacy allows a state to achieve its economic interests "tactfully, politely, carefully, cleverly and cunningly" (OkanoHeijmans, 2011). It stimulates the state's economic interests, creates a viable and profitable environment for economic cooperation among different actors, and expands its sphere of influence. It not only involves trade and investment but also entails mobilizing international assistance to resolve conflicts.

Relations between states are enhanced when diplomatic skills are combined with economic tools to further a country's political, economic and strategic goals. More clearly, it is deployed for improving import-export relations, promoting national economic interest, informing potential foreign investors about investment opportunities, negotiating economic and trade cooperation to eliminate problematic divergences and harmonising standards in various sectors, e.g., economic, social, environment and education, among others (Okano-Heijmans, 2011). Economic diplomacy includes political involvement, especially high-ranking politicians (ministers), along with bureaucrats; sharing of duties and responsibilities by involving non-state actors, including private business and civil society; transparency during the implementation of a policy to broaden understanding and support by society; and use of facilities and provisions of international institutions and organizations to ensure implementation of economic goals (Economic Diplomacy, 2013). It is exercised at the bilateral, regional and multilateral levels, and requires tactfulness to exert influence on foreign government policy and regulatory decisions. Economic diplomacy at the bilateral level is exercised with the help of agreements on trade, investment, employment, taxation and a wide range of formal and informal economic regulations between two countries. Bilateral free trade agreements are signed and implemented between countries. Similarly, economic diplomacy at the regional level is concerned with agreements between more than two countries in a region driven by geographical proximity and homogeneity. The removal of barriers and the opening of markets become easier within a regional framework. A region with connectivity and homogeneity enhances national 
economic interests and boosts economic liberalisation, which highlights the growing importance of regional cooperation in economic diplomacy (Wolff, 2017). Economic diplomacy at the multilateral level operates with trade regimes such as within the framework of the World Trade Organization (WTO). Since its establishment in 1995, trade between countries is increasingly governed by international regulations. International economic and financial organisations, such as the World Bank (WB), International Monetary Fund (IMF) and various UN agencies, promote a multilateral form of economic diplomacy (Lee \& Hocking, 2010). Thus, economic diplomacy encompasses the economic and commercial aspects of traditional diplomacy and focusses on the interdependence and interconnectedness of state and non-state actors, such as trade and investment promotion bodies, chambers of commerce and civil society in the international system.

Apprehending the increasing level of reciprocity and interdependence, a coordinated economic diplomacy strategy suits Nepal to bolster its development and economic growth. Therefore, engaging with literature on economic diplomacy and strategies to enhance coordination among the actors, this study revisits Nepal's economic diplomacy practices and presents robust strategies to enhance the economic diplomacy strategies for Nepal.

\section{Methodology}

As a qualitative research, this study reviews Nepal's economic diplomacy practices and recommends coordinated economic diplomacy for Nepal's development and economic growth. Methodologically, a systematic, subjective and holistic approach has been opted. The author has also included details from the consultations and discussions of the High-Level Task Force/ MOFA (2017/18). The consultations were held with the MOFA division heads, overseas mission heads, including present/former diplomats, relevant line ministries, private sector, Nepal Tourism Board (NTB), Federation of Nepalese Chambers of Commerce and Industry (FNCCI), political leaders and civil society. Academic literature on economic diplomacy was referred to for the study, and data were collected from reports of the ministries, National Planning Commission, NTB and other agencies.

\section{Results:}

\section{Nepal's Experience with Economic Diplomacy}

Nepal attempted to adjust its foreign policy after the restoration of multiparty democracy in 1990. Towards this end, it established a division under the Ministry of Foreign Affairs (MOFA) intending to institutionalise economic diplomacy (Dahal, Sainju, Lohani, Sharma, \& Parajuli, 2008). A 
broad concept of "development diplomacy", which includes policy dialogue and policy negotiation in international development, has been the principle of MOFA to further Nepal's development agenda in the international sphere (Pokharel, 2017). At present, the Policy Planning, Development Diplomacy and Overseas Nepalese Affairs Division at MOFA, along with its overseas missions, is responsible for Nepal's economic diplomacy. The division's main task is to focus on promoting and improving foreign trade, investment, technology transfer, tourism, development cooperation, foreign employment and climate change (MOFA, 2020). MOFA's efforts and effectiveness to engage in economic diplomacy have been questioned and criticised. The results of more than two decades have been obscure as evidenced by the minimal rise in national GDP. Budgetary and inadequate resources have often been cited by officials for their poor performance. But what is lacking is committed leadership and skills in managing negotiations and public relations in international forums. Firstly, the allocated budget for activities to promote economic diplomacy by the Government of Nepal (GON) is NRs 140 million (Giri, 2020), which is not sufficient to implement plans and strategies. Secondly, GON has overlooked actions and policies required to increase FDI, foreign employment, tourists, and narrow the trade deficit. It is instead focused on setting a wish list rather than applying real efforts (Dahal R. K., 2018). Thirdly, economic diplomacy practices are limited to lobbying in the host country for favourable policies towards Nepal, including lobbying for priority destination country for tourists, removing quota restrictions on Nepali products and entering into bilateral agreements to ensure labour safety, security and dignity in the labour destination countries. Nepal's Millennium Development Goal (MDG) experience, planning and implementation of the Sustainable Development Goals (SDGs) and the country's target to graduate from a least developed country (LDC) by 2022 to a middle-income country by 2030 are, however, noteworthy attempts. (National Planning Commission, 2016).

Economic diplomacy is an indispensable instrument to secure Nepal's foreign policy objectives and economic advancement. The country's ability to engage in economic diplomacy for national prosperity can be facilitated by leveraging on its abundant natural resource base, rich biodiversity and cultural heritage. Besides, a booming service sector and rising private business enterprises equally contribute to creating a distinct possibility for Nepal to boost trade and investment opportunities through international relations (Yadav, 2018). As a member of global trade regimes such as the WTO and regional and sub-regional forums, including SAARC, BIMSTEC, BBIN, BRI, etc., it has utilised trade privileges such as duty-free and quota-free access (Sharma, 2018). At present, GON engages in development/economic diplomacy at three levels: bilateral, regional and multilateral. The country has directed diplomatic efforts and set 
up targets to increase the level of engagement with friendly states to market goods and services, and implement and review periodic plans, SDG agenda and a LDC advancement strategy. Nepal has planned and implemented a sustainable, inclusive and green growth-oriented development strategy for the coming decades to achieve a higher per capita income, reduce poverty, enhance human capital and improve the living standards of vulnerable populations.

There is recognition within GON that coordination between the various ministries is essential. However, the High-Level Committee at MOFA has not been effective. Policymakers have not laid out a framework for identifying destination countries for global export, ways to attract foreign investment and other forms of economically beneficial exchanges where Nepal enjoys a comparative advantage. This can only happen through coordinated and cooperative collaboration of the relevant line ministries and non-state actors such as trade and investment promotion bodies, chambers of commerce and civil society. To compound the problem, MOFA does not have the capacity to engage other line ministries and non-state actors to tackle the diverse and complex issues. As a result, there is coordination failure with the stakeholders in Nepal and missions abroad. For instance, comparative advantage and economy of scale are important considerations for the Ministry of Finance as it is related to the economic policy at home. However, the role of overseas missions in attracting foreign business and negotiating free trade and/or preferential trade agreements is largely ignored by the Ministry of Finance. Another example of coordination failure is in implementing tourism promotion activities. MOFA must coordinate with the NTB, which has a large budget allocated for tourism promotion. The NTB not only promotes attractive destinations within Nepal but also carries out promotional activities abroad and provides published materials to overseas missions, but often without input and participation of MOFA or overseas missions. There is no coordination or synergy in the effort (Pandey \& Dhakal, 2019). Furthermore, MOFA has not demonstrated leadership to drive economic diplomacy. It has not kept abreast with new modes of diplomacy, which mandates going beyond pursuing state-centric analyses of primarily political agendas to searching for competitive advantage in the world economy. Also, overseas mission staff lack new skills and are also constrained by communication barriers, especially where knowledge of the local language is important, i.e., Gulf countries, China, Russia and Japan, among others.

Another reason for the ineffectiveness of our economic diplomacy is not only related to the practices but also to the inability of Nepali industries and exporters to meet import demand due to supply constraints (Asian Development Bank, 2020). Diplomats and overseas missions must inform the Ministry of Finance, trade and investment promotion bodies, chambers of commerce and policymakers about international trade regulations. And as the occasion demands and opportunity permits, they must have the capacity to negotiate 
international trade regulations to Nepal's benefit. In essence, diplomats and overseas missions must acquire new skills for directing private investments towards products considering demand, competitiveness, advantage and cultural specificity (Wolff, 2017).

\section{Coordinated Strategy for Strengthening Economic Diplomacy}

Nepal's geo-political and geo-economic situation remains a major determinant in the conduct of relations with other states. Its geostrategic position warrants country-specific treaties. For instance, while a comprehensive long-term strategy regulating relations between India and China is essential, engagement with the US and EU would be different, as would with the Gulf countries and Malaysia (Dahal, 2018). Overseas missions are key players in negotiations and in disseminating the uniqueness of Nepal in the international economy. In the pursuit of economic security, especially as the country is highly dependent on remittance, new marketing strategies are needed to promote Nepal as a tourism destination. Congruent strategies for foreign employment are important, and the same goes for FDI and trade (Ministry of Foreign Affairs, 2020).

MOFA and overseas missions need to have a clearer understanding of the interdependence of economic, political and social issues, and the linkages between state and non-state players in the international system (Bhattarai, 2018). Private sector engagement stems from the need to remain competitive as trade between states is increasingly being governed by international regulations (National Planning Commission, 2019). Involvement of civil society on the other hand becomes necessary to ensure that the interests of grassroots stakeholders are taken into account in international negotiations. Hence, the strategy for coordinated economic diplomacy includes:

\section{Institutional Preparedness and Coordination}

Strengthening MOFA's institutional capacity and preparedness for this role is of paramount importance. Improving managerial capacity and acquiring new knowledge and negotiation skills are a prerequisite in the practice of economic diplomacy. Effective economic diplomacy not only mandates institutional preparedness of MOFA but also of other ministries and organisations, such as the ministries of Finance, Industry, Commerce and Supplies, the Office of the Prime Minister, NTB and other relevant agencies. To realise this, integrated and effective coordination operating under a broad framework with clear operating procedures is required.

Research and development (R\&D) through strong and dynamic think tanks, such as the Institute for Foreign Affairs (IFA), can support coordination and articulation framework. One way to improve coordination is by forming policy networks drawn from different line ministries, including trade and investment 
promotion bodies, for multilateral, regional and bilateral engagements. Such networks provide business intelligence, tourism marketing and partner searches. Towards this end, GON must identify bilateral economic and development partners and formulate an actor-specific strategy to optimise bilateral relations; regularly evaluate economic relations between Nepal and development partner countries and identify benefits and shortcomings; formulate basic development policies and periodic development plans within the framework of the long-term development perspective and programmes of the National Planning Commission; set up annual targets with objective indicators and assess plans and policies; intensify implementation of action plans through innovation and analysis and assess current trends and economic relations with partner countries; evaluate feedback collected from non-state actors, including trade and investment promotion bodies, chambers of commerce, related stakeholders, and building partnership with them in implementing strategies; attract Nepali diaspora to invest in Nepal; carry out economic negotiations and initiate a memorandum of understanding for economic cooperation; perform periodic reviews and updates of the agreements and MoUs; and conduct a thorough analysis of the possible impact of partner states' economic policies and raise voice against possible adverse impact.

To enable MOFA in playing a catalytic role in ensuring synergy in policies and plans, the focus is on securing a commitment from the sector ministries and building a strong and functional mechanism at a high level for inter-ministerial cooperation and coordination; regular interaction, dialogue and consultations with the concerned sectors, including politicians, bureaucrats, business and trade unions, NGOs and donors; building a critical pool of staff with new skills and knowledge on economic diplomacy; regular assessment of feedback from the private sector, such as the FNCCI, Confederation of Nepalese Industries (CNI), Nepal Chamber of Commerce and others. Activities that are specifically needed to improve performance in economic diplomacy include:

- $\quad$ Playing a proactive and assertive role in coordinating different agencies and stakeholders related to economic affairs to make the work of MOFA and overseas missions efficient and effective;

- Holding regular consultation between concerned MOFA officials, especially desk officers, and missions abroad and promptly responding to the communications received;

- $\quad$ Organising at least a biennial visit by MOFA officials to the missions;

- Preparing, updating and sharing with overseas missions briefing materials on trade, investment, tourism, foreign assistance and other related areas, including materials prepared by other agencies/missions;

- Formulating a policy to recruit local staff with local language capability, 
including lawyers, especially in countries where missions have to deal with legal issues;

- $\quad$ Training MOFA staff on economic diplomacy through an institutional setup (focussing on making missions business-friendly, imparting knowledge in the areas of trade, investment, tourism, customs procedure, company registration, economic priorities;

- Providing pre-departure training to diplomats posted in the missions, including a separate module to cater to country-specific needs and situation;

- $\quad$ Preparing Terms of Reference (TOR) for ambassadors, clearly stating the goals and priorities for promoting the country's economic interests and enhancing economic ties with the country of assignment;

- Monitoring the efforts of diplomats through a process of incentives and disincentives to make them accountable (High-Level Foreign Policy Task Force, 2006);

- Encouraging diplomats and missions to work with like-minded countries in restructuring and reforming financial institutions in favour of the developing, least developed and landlocked developing states (Dahal, Sainju, Lohani, Sharma \& Parajuli, 2008);

\section{Multilateral and Regional Engagements}

A systematic approach and a clear framework for cooperation, coordination and management should be established for multilateral, regional and bilateral engagements. There are different multilateral and international agreements such as the WTO, United Nations Convention on Law of the Sea (UNCLOS), Paris Agreement on Climate Change, etc. Also, international financial institutions facilitate freedom of transit and enable preferential trade for the Landlocked Developing Countries (LLDCs) and the Least Developed Countries (LDCs) (World Bank, 2014). One major and effective level of economic engagement other than bilateral is regional and multilateral arrangements. Regional agreements such as the South Asia Free Trade Agreement (SAFTA) and South Asia Preferential Trading Arrangement (SAPTA) and regional/sub-regional organisations such as BIMSTEC and BBIN can strategically maximise advantage regarding connectivity, reduce non-tariff barriers in exports and enhance transit facilities, tourism, electricity, trade and investment. Thus, through these instruments on trade and transit facilitation, Nepal could benefit economically and boost Nepal's economic diplomacy (South Asia Sub regional Economic Cooperation, 2019). 
Creating new alliances and building networks of business groups based in overseas missions are crucial for economic stability. Nepal can engage with other South Asian countries through regional trade agreements and strengthen the existing regional trade instruments, viz. SAFTA, SAARC and SAPTA (SWATEE, 2007). Also through economic diplomacy, Nepal has the potential to enter new foreign markets outside south Asia through the Bay of Bengal Initiative for Multi-Sectoral Technical and Economic Cooperation (BIMSTEC) and sub-regional organisations like BBIN (South Asia Sub regional Economic Cooperation, 2019). Exploiting and accessing new markets for goods and services is becoming increasingly urgent in view of the fact that the country's economy is heavily dependent on India. At the multilateral level, the focus should be on securing fair competition for Nepali products in the international market. This can be facilitated by participating in exhibitions, fairs in the targeted countries, organising international forums to attract export promotion and developing a strategy for lobbying to defend national economic interests (South Asia Sub regional Economic Cooperation, 2019). Similarly, civil society must be enabled so that they can also operate at the regional and multilateral level. The multilateral strategy includes increasing interaction and interdependence of national economies, multinational corporations and international organisations for Nepal (SWATEE, 2007).

Overall, at both the regional and multilateral level the focus is on facilitating trade and business investment, promoting Nepal as a diversified tourist destination, easing the movement of skilled, semi-skilled and unskilled labour force, and cooperating in science and technology, including research and development.

\section{Technology Transfer}

Access to technology and its adoption in economic development to a large degree decide a country's competitive position in the international labour division (Booth, 2018). Hence, economic diplomacy should incorporate technology transfer for improving productive capacity and structural transformation. It includes innovation, open economic policies for investment and securing intellectual property rights, among others. Nepal should pursue approaches for access to and transfer of technology, including sharing and disseminating knowledge and skills, and economic diplomacy focussing on the transfer of scientific discoveries, production methods and other innovations at affordable terms and conditions. Engaging proactively with UN technology banks for the LDCs would be an added asset (NPC and ADB, 2016). 
Nepal's aspiration to be a vibrant bridge between the two Asian giants and the prospect of trilateralism could be realised through coordinated economic diplomacy with other technologically advanced states through technology transfer. Also, Nepal's trade should be focussed on technological information learning capacity, and the strategy should focus on inviting Multinational Enterprises (MNEs), as quite often MNEs transfer technological information to their affiliates, some of which may "leak" into Nepal's economy. Another major technological strategy for Nepal through coordinated economic diplomacy could be direct trade in knowledge via technology licensing (United Nations Conference on Trade and Development, 2013).

As technology transfer also depends upon people's movement, the Nepali diaspora, NRN and other Nepalis working abroad can become a channel for technology transfer. International movement of Nepali people associated with studying or working abroad for a limited period and applying their new knowledge when they return or the movement of foreign nationals into the country is another potential channel for technology transfer, and thus Nepal's economic diplomacy should focus on these. Technology-related policies should be friendlier for the foreign investors, while the national policies should be welcoming for international cooperation (Westphal, 2006). Therefore, there are diverse areas for technology transfer, technological progress and innovation in countries at different levels of development. So Nepal's coordinated economic diplomacy must incorporate strategies for technology transfer and innovation.

\section{Sector Promotion}

Nepal's export of goods and services was $8.93 \%$ (of GDP) while import of goods and services was $42.38 \%$ in 2019 (World Bank, 2019). Similarly, its trade deficit stood at NRs 69,737.30 million in May 2020 (Trading Economics, 2020). To address these challenges, GON has promoted foreign trade, in general, and export trade, in particular. Export promotion can be supported by analysing the market situation in the destination states to competitively and advantageously benefit and increase export; seeking support from the Nepali diaspora, private sector and agencies like the Trade and Export Promotion Centre (TEPC) to develop a trade promotion strategy (Trade and Export Promotion Centre, 2020); promoting visits of delegations of Nepali exporters with the involvement of overseas missions; follow-up by overseas missions on deliberations and decisions of the delegation's meetings with the host country; providing information regarding export products, branding, etc., through interaction with the chambers of commerce; encouraging Nepali delegations to participate in trade shows and exhibitions by providing information on such 
events to relevant organisations and individuals; creation of duty drawback schemes and increasing the availability of short and long-term credits to Nepali exporters; simplifying trade regulations, improving cooperation among economic actors and combining short-term and long-term export growth policies (Richter, 2017).

Sector promotion seeks regular market analysis by MOFA with the assistance of the Ministry of Industry, Commerce and Supplies, and the private sector. The obtained information should be shared with missions abroad. Periodic analysis enhances trade promotion and identifies a priority commodity for promotion. A specific-purpose and interest-based visit and participation in trade fairs and exhibitions should be conducted. Also, Nepal should hold trade fairs and exhibitions of an international nature to promote trade, and the cost should be shared by GON to create a conducive environment for trade promotion (Pant, 2011).

\section{Investment Promotion}

Nepal should focus on increasing investment, including commercial loans, official flows, foreign direct investment (FDI) and foreign portfolio investment (FPI) to enhance economic growth. Though foreign investments are increasing in Nepal, foreign direct investment, net inflows is $0.23 \%$ (of GDP) in 2018 (World Bank, 2018). Thus, FDI promotion should be the major priority to enhance economic development. Economic diplomacy should be carried out by disseminating information about Nepal's potential as an FDI destination country by updating details about priority sectors, available projects and market situation; making investors aware of GON's adoption of the concept of Special Economic Zones (SEZs), Industrial Estates and potential trade corridors in Nepal; taking advantage of the Everything But Arms (EBA) initiative under the EU Generalized System of Preferences, preference given by India and proximity to large Indian and Chinese markets (Bhandari, 2014); regulating amendments by GON regarding legal and procedural improvements on the Industrial Enterprise Act, Companies Act, SEZ Act, Foreign Investment and Technology Transfer Act and Labour Act (United Nations Conference on Trade and Development, 2003); encouraging and promoting visits of business delegations from potential FDI source countries and facilitating contacts with government agencies and potential partners, if the partner country is willing to invest, then facilitating contacts with local partners (Aryal, 2018); providing information to potential investors of facilities provided to ensure the protection and enhancement of companies or projects; promoting and safeguarding the corporate interest of investment partners in Nepal's interest; providing successful FDI case studies 
(like accounting firms of multinationals, Kobold watch, Incessant Rain, Cloud factory) to encourage investment in Nepal (Booth, 2018).

\section{Intensification of Tourism Promotion}

Nepal enjoys comparative advantage in tourism. The world's highest peaks, national parks rich in flora and fauna, snow-fed rivers, exceptional trekking routes, religious and cultural diversities, and adventure tourism place Nepal among the top destinations for tourism. Hence, economic diplomacy must include strategies to boost tourism. Examples to support the development of tourism include increasing government expenditure in the tourism sector for new infrastructure, such as airports, trails, tourism attractions and facilities; attracting investment from the private sector in creating tourism facilities; organising international tourism promotional campaigns, activities and festivals in various parts of Nepal and the world through overseas missions, through collaboration and coordination with relevant government ministries, non-governmental agencies, travel trade entrepreneurs and other stakeholders; applying sustainable development principles in tourism by minimising the environmental impact and maximising local ownership; promoting Nepal as a destination country through campaigns in partnership with overseas missions and the private sector; accelerating regional tourism in source markets like India, China and southeast Asia (Ministry of Tourism and Civil Aviation, 2019).

\section{Labour Diplomacy}

Nepal has signed bilateral labour agreements and MoUs with nine countries as of July 2019, of which most are less binding in nature. However, Nepal sends youths and workers to more than 110 countries (Ministry of Labour, Employment and Social Security, 2020). In the absence of a MoU or an agreement with a host country, Nepali workers' rights cannot be protected. Hence, there is an urgent need for signing country-specific labour agreements to protect the welfare of Nepali workers. Alternatively, Nepal could attract these countries to establish training centres in Nepal so that there is a match in skills required for the host country. The prospect of well-trained human resources may attract them to sign labour agreements with Nepal (Luitel, 2013).

One of the objectives of the overseas mission is protecting Nepali migrants, and accordingly, the staffs are assigned specific tasks for meeting this purpose. However, missions in this particular service have not been effective for lack of communication skills in the local language. A policy to hire local staff could be introduced, which is also cost-effective. As the labour market is highly 
competitive, the search for labour markets should be coordinated with the Foreign Employment Promotion Board to promote foreign employment in a professional, safe and ethical manner (International Organization for Migration, 2019). To protect Nepali migrant workers and enhance foreign employment, there is a need to sign mutually beneficial MoUs with labour receiving countries, where agreements reflect the provisions in international treaties/covenants, address migrant workers' concerns in the destination countries and reflect agreements reached in regional consultations; address and resolve labour issues in the host country promptly by removing constraints in Nepal and overseas missions; equip missions with local staff having sufficient language and other skills; review and update existing labour agreements, especially those that have failed to protect the interests of Nepali workers; assess recruitment fees and the process to make it friendly and easy to facilitate foreign employment; set up a high-level implementation, monitoring and evaluation mechanism to ensure effective, safe, professional and ethical foreign employment. MOFA and its overseas missions should explore the possibility of reducing the cost of migration, which is one of the highest for Nepali workers. As there is high competition in the international labour market, diversified foreign employment opportunities need to be properly analysed for better human rights conditions and salary/benefits (Luitel, 2013). Enhancing skills and establishing training centres with support and/or accreditation of the host countries should be explored.

\section{Foreign Assistance}

Nepal's economy and development projects are highly dependent on foreign assistance. Economic diplomacy and foreign assistance are related to the nation's economy and prosperity, especially for a developing country (Aryal, 2018). Thus, missions abroad should be mobilised for identifying and taking support from the development partners. As a first step, all diplomats and overseas missions should be made aware of Nepal's priority areas for assistance, strategy for achieving SDGs, graduating from a LLDC and becoming a middle-income country by 2030 (National Planning Commission, 2019). In line with this, missions need to focus on attracting more assistance in Nepal's priority areas (infrastructure, productive capacity, employment generation, capacity-building) rather than technical assistance for policy and governance issues through negotiations and consultations (NPC and ADB, 2016); keeping abreast of partner outlook on investment sectors, and disseminating Nepal's perspective to them; analysing the context of changing foreign assistance policy in international society; securing non-conditional assistance under the framework of relevant declarations, and developing 
action plans for aid effectiveness; acquiring aid for projects and programmes with substantial resources, and which can have a significant impact on the country's priority areas; identifying and exploring new avenues and sources of aid, and facilitating their entry into Nepal (Asian Development Bank, 2020); prioritising the short- and long-term aid priorities of Nepal to the development partners; securing as much assistance as possible from priority funding schemes applicable to Nepal as a LDC (UNESCAP, 2018); expediting disbursement of agreed assistance; and encouraging only "reputed" INGOs to enter and operate in Nepal. To increase foreign assistance, Nepal could focus on formulating economy-wide and sector perspective plans, ensure transparency and accountability, enhance quality aid, and strengthen aid coordination while promoting institutional effectiveness (NPC \& ADB, 2016). Similarly, Nepal can improve foreign assistance through improved project planning and implementation, evaluation, impact study, and supervision and monitoring.

Also, the Nepali diaspora in coordination with MOFA can engage in economic development and diplomacy. GON through MOFA can effectively mobilise the Nepali diaspora community to secure foreign assistance by mapping Nepali diaspora locations and skills for advocacy and lobbying; opening a regular channel of communication with the diaspora through the NRN Secretariat and engaging them in regular dialogue (Aryal, 2018); focussing on diaspora capital markets and encouraging them to invest directly; developing a mechanism of "Diaspora Knowledge Network" to tap their knowledge and networking with politicians and business communities in their country of residence to promote Nepal's economic agenda; encouraging the concept of "Diaspora Philanthropy" through cultural centres established by them in different cities of the world to promote Nepal's soft power diplomacy through culture and tourism (Boyle \& Kitchin, 2013); updating NRN Rules 2009 to clarify unclear/confusing interpretation of the current NRN Act 2008 in line with the provisions of Nepal's constitution; creating a "Diaspora Corp" for knowledge transfer (Booth, 2018); and supporting returnee migrants to create jobs in Nepal (So far, there are no specific schemes promoted by the public sector to channel migrants' investment in the productive sector) (High-Level Foreign Policy Task Force, 2006).

\section{Partnership with the Private Sector}

Nepal's $15^{\text {th }}$ Five-year Development Plan from 2019/2020 to 2023/24 AD expects the private sector to invest nearly $55.5 \%$, or NRs $5,135.41$ billion, the government $39.1 \%$, or NRs 3,613.32 billion, and the cooperative sector $5.4 \%$ (NPC, 2019). This demonstrates that efforts to promote economic 
diplomacy cannot be effective without partnership with the private sector. Its role in economic diplomacy could be enhanced by strengthening the existing institutional mechanism for regular dialogue between GON and the private sector, both at MOFA and in overseas missions; formulating a strategy for a result-oriented partnership for promoting trade, tourism, investment and employment; creating a strong agency in MOFA consisting of the head of the umbrella body of the private sector, secretaries of the related sectoral ministries and professionals to functionally link the private sector and MOFA, embassies and missions (Shrestha, 2006); planning and implementing joint promotional and business activities; and promoting foreign visits of Nepali business delegations and facilitating/hosting their meetings in missions.

Also, the private sector in collaboration with the government can promote local economic development by utilising local knowledge, skills, and resources and link it with long-term economic growth. The government should collaborate with trade and investment promotion bodies and pool its resources with the private sector for promotional programmes related to economic diplomacy (Ministry of Foreign Affairs, 2020). Moreover, proper coordination and consultation with the private sector before formulating plans and policies are essential. A strong private sector with strong leadership can contribute to effective and coordinated economic diplomacy through collaboration and cooperation with the private sector in different states. The private sector can help bring in FDI as well as in technology transfer (Basnyat, 2011). Thus, the private sector has a big role to play in economic diplomacy than just investing money.

\section{Business-friendly Missions}

One primary objective of overseas missions is to develop and promote economic relations between the home and host countries and maximise the benefits from such relations. Thus, missions should create an environment that is welcoming and friendly to business promotion. Missions should be equipped with information related to opportunities available to the investors and analyse market efficiency and competitiveness in the host country (Rana \& Chaterjee, 2011). Its role is to facilitate. Tasks include maintaining a comprehensive and updated website; responding promptly to business enquiry; introducing relevant people and agencies from home to host country business people; helping create contacts and linkages with business communities; supporting consular/consul general offices to make them effective and monitoring their activities; and maintaining a business network with a comprehensive mailing list of relevant people in the host country; MOFA, on its part, must develop 
a mechanism to monitor and collect information on current issues or theme papers prepared by various agencies and share them with its missions.

\section{Networking}

Strengthening networks and creating a sphere of influence are an important aspect of economic diplomacy (Kostecki \& Naray, 2007). Therefore, the focus is on creating networks not only with the governments of other countries but also with multinational corporations, development partners, financing institutions and even individuals (Bhattarai, 2018). Regional and multilateral platforms are one of the important instruments to promote networking, but other agencies can also enhance networking. Say, for example, "Friends of Nepal", which provides a platform for networking and sharing information. Networking can be strengthened by establishing a caucus of parliamentarians on issues related to Nepal through the support of overseas missions and organising regular briefings to them and their staff on Nepal; emphasising policies that enhance foreign investment and trade with Nepal; developing connections with the chambers of commerce of other countries and organising interactions with them; preparing a list of potential investors, commercial institutions and personalities and interacting with them in person to build trust and confidence; establishing linkages with think tanks and universities, especially those with a focus on Nepal studies; maintaining a list of "Nepal lovers and supporters" and communicating with them; keeping regular contact with government officials in the network of a mission; using NRN and the Nepali diaspora to promote linkages with various stakeholders; and creating a stakeholder database to institutionalise such networking.

\section{Monitoring and Supervision}

Monitoring and supervision of plans and policies and, if necessary, rethinking about them are important for efficient economic diplomacy. For this, MOFA should have clear guidelines to enable it to assess and monitor activities. Autonomy to conduct and take the necessary steps for improving economic diplomacy should be the purview of the division under MOFA. Other divisions of the concerned ministries and the High-Level Economic Diplomacy Implementation and Monitoring Committee under the chairmanship of the foreign minister should be made effective to independently monitor progress.

Equally, the secretary-level committee representing all the concerned line ministries should be formed for multi-sector support and direction (Dahal, Sainju, Lohani, Sharma, \& Parajuli, 2008). Its task includes assessing policy announcements of the host countries vis-à-vis Nepal and the potential for partnership. 


\section{Conclusion}

This study has discovered that in the context of an increasingly globalised world, where states cannot escape economic interdependence, and economic diplomacy has become the unavoidable reality of 21 st century international relations, the intricacies of the interactions among the state and non-state actors imply that economic diplomacy cannot be compartmentalised into separate economic or geo-economic realities of countries like Nepal, making it crucial to formulate and implement economic diplomacy to maximise benefits from international relations. This study also identified that the main focus of economic diplomacy should be on trade promotion, investments, technology transfer and tourism. Current trends in a globalising economy warrant enhancing collaboration between the state and non-state actors, given the increased importance shown to international trade rules and regulations, which need to be negotiated and implemented.

Thus, it has been realised that coordinated diplomacy must be built around networks drawn from several government ministries as well as the private sector and civil society. Regarding this, MOFA should expand its institutional capabilities to drive economic diplomacy and find ways to interact effectively with other line ministries and non-state actors. Success to a large extent will depend on new skills, capability, tact and versatility of the staff engaged in the conduct of economic diplomacy. Therefore, Nepal's coordinated economic diplomacy strategies should retrospectively learn from its economic diplomacy practices and experiences. And to strengthen coordinated economic diplomacy in the changing world, it should focus on institutional preparedness and coordination, increase multilateral and regional engagements, enhance technology transfer strategies, emphasise sectoral investment and tourism promotion, strengthen labour diplomacy, attract foreign assistance, prioritise partnership with the private sector, promote business-friendly missions, and, importantly, concentrate on networking, monitoring and supervision.

\section{References}

Agbevade, A. (2018). Local Economic Development Strategies and Challenges: A Comparative Empirical Study. Journal of Public Administration and Governance, VIII (4), 104-118. DOI:10.5296/jpag.v8i4.13894

Aryal, B. (2018). A Study of Foreign Aid Mobilization in Nepal. Kathmandu: Ministry of Foreign Affairs.

Asian Development Bank. (2020). Macroeconomic Update- Nepal. Kathmandu: Asian Development Bank.

Basnyat, R. (2011). International Market Access. In P. Pradhan (Ed.), Economic Growth and the Private Sector of Nepal (pp. 145-174). Kathmandu: Samriddhi Foundation. 
Bhandari, G. R. (2014). Has the Generalized System of Preferences Scheme Influenced Nepalese Exports to the United States? An Empirical Analysis. Economic Journal of Development, XVII (2), 29-39.

Bhattarai, M. K. (2018). Recent Trends in Nepal's Foreign Policy, and Role and Functions of Our Diplomats. Journal of APF Command and Staff College, 76-81.

Booth, D. (2018). Incubating Policy for Economic Transformation. London: Overseas Development Institute.

Boyle, M., \& Kitchin, R. (2013). Diaspora for Development: In Search for a New Generation Diaspora Strategies. In Y. Kuznetsov (Ed.), How Can Talent Abroad Induce Development at Home? Migration Policy Institute.

Dahal, M. K., Sainju, M. M., Lohani, M. P., Sharma, S. P., \& Parajuli, U. (2008).A Generic Guideline for Development through Economic Diplomacy. Institute of Foreign Affairs.

Dahal, R. K. (2018).The need for Change in Contemporary Nepalese Foreign Policy. Journal of Political Science, XVIII, 82-113.

Economic Diplomacy. (2013). In A. F. Cooper, J. Heine, \& R. Thakur (Eds.), The Oxford Handbook of Modern Diplomacy. The Oxford University Press.

Giri, A. (2020, July 26). Nepal's budget for economic diplomacy not enough, say experts. Retrieved from The Kathmandu Post: https://kathmandupost.com/ national/2020/07/26/nepal-s-budget-for-economic-diplomacy-not-enoughsay-experts

High-Level Foreign Policy Task Force. (2006). Renewing Nepal's Foreign Policy in the Changing Context. A Report Submitted by Murari Raj Sharma et al. to Ministry of Foreign Affairs, Government of Nepal, August.

International Organization for Migration. (2019). Migration in Nepal. Kathmandu: International Organization for Migration.

Kapustina, L., Lipková, L., Silin, Y., \& Drevalev, A. (2020).US-China Trade War: Causes and Outcomes. Creative Commons Attribution License 4.0.doi:https://doi. org $/ 10.1051 /$ shsconf $/ 202073010$

Kostecki, M., \& Naray, O. (2007). Commercial Diplomacy and International Business. Netherlands Institute of International Relations Clingendael.

Lee, D., \& Hocking, B. (2010). Economic Diplomacy. The International Studies Encyclopedia, 1216-1227.

Luitel, S. (2013).Study on Nepal's Bilateral Labor Agreements with Destination Countries. Ministry of Foreign Affairs. (2020, May 4). Policy Planning, Development Diplomacy and Overseas Nepalese Affairs Division. Retrieved from Ministry of Foreign Affairs.

Ministry of Labor, Employment and Social Security. (2020). Nepal Labor Migration Report 2020. Kathmandu: Government of Nepal.

Ministry of Tourism and Civil Aviation. (2019). Tourism Vision 2020. Kathmandu: Government of Nepal.

National Planning Commission. (2016). Nepal's Sustainable Development Goals. 
Kathmandu: Government of Nepal.

National Planning Commission. (2019). Fifteenth Plan (FY 2076/77-2080/81). Retrieved from National Planning Commission: https://www.npc.gov.np/images/ category/15th_Plan_Final1.pdf

National Planning Commission and ADB. (2016). Envisioning Nepal 2030. Kathmandu: Government of Nepal.

Okano-Heijmans, M. (2011). Conceptualizing Economic Diplomacy: The Crossroads of International Relations, Economics, IPE and Diplomatic Studies. The Hague Journal of Diplomacy, 7-36.

Pandey, R., \& Dhakal, R. K. (2019). Visit Nepal Year 2020: Some Imperatives. Journal of Social Science Research.

Pant, B. (2011). Nepal's Trade Sector: Review, Repercussions and Recommendations. Economic Review, 86-112.

Pokharel, K. (2017). A Critical Overview of Nepal's Economic Diplomacy: Prospects and Constraints. The Nepalese Journal of Public Administration, 144-150.

Rana, K. S., \& Chaterjee, B. (2011).The Role of Embassies. In Economic Diplomacy: India's Experience. CUTS International.

Richter, P. (2017). Trade Promotion in Nepal: 'An Impossible Task?' A Case Study on a Landlocked Least Developed Country. Foreign Trade Review, LII (1), 48-59.

Saner, R. (2012). Development Diplomacy by Non-State Actors: An Emerging Form of Multistakeholder Diplomacy. In The Expert Negotiator. Martinus Nijhoff.

Sharma, R. (2018). Potentials of Nepal and North-East India to link South Asia and South East Asia. The Annual Journal, 83-90.

Shrestha, R. (2006, August 8). Economic Diplomacy: A Private Sector Perspective. Retrieved from The Himalayan Times: https://thehimalayantimes.com/ opinion/economic-diplomacy-a-private-sector-perspective/

South Asia Sub-regional Economic Cooperation. (2019). Potential Exports and Non-Tariff Barriers to Trade: Nepal National Study. Asian Development Bank.

SWATEE. (2007). Trade Negotiation Strategy for Nepal. Kathmandu: South Asia Watch on Trade, Economics \& Environment (SAWTEE) and ActionAid Nepal (AAN).

Trade and Export Promotion Centre. (2020). Trade and Export Promotion Centre's Profile. Retrieved from the Trade and Export Promotion Centre: https://www.tepc.gov. $\mathrm{np} /$ pages/about-us

Trading in Economics. (2020). Nepal Balance of Trade. Retrieved from Trading Economics: https://tradingeconomics.com/nepal/balance-of-trade

UNESCAP. (2018). Investment Policy and Regulatory Framework in Nepal, FY 2073-74 (2016-2017). Kathmandu: UNESCAP.

United Nations Conference on Trade and Development. (2003). Investment Policy Review: Nepal. Geneva: United Nations.

United Nations Conference on Trade and Development. (2013). Transfer of technology and knowledge-sharing for development. United Nations Publications.

Westphal, L. E. (2006). Technology Strategies For Economic Development In A Fast- 
78 Institute of Foreign Affairs, Nepal : Journal of Foreign Affairs, Vol. 1, No. 1, Jan 2021

Changing Global Economy. Economics of Innovation and New Technology, 275-320.

Wolff, S. (2017). Economic Diplomacy and Connectivity. Institute for Conflict, Cooperation and Security. The University of Birmingham.

World Bank. (2014). Improving Trade and Transport for Landlocked Countries. World Bank. Retrieved from https://www.worldbank.org/content/dam/Worldbank/ document/Trade/Landlocked_Countries.pdf

World Bank. (2018). Foreign direct investment, net inflows (\% of GDP). Retrieved from The World Bank: https://tcdata360.worldbank.org/indicators/ BX.KLT.DINV.WD.GD.ZS? country=NPL\&indicator $=1541 \& \mathrm{viz}=$ line chart\&years $=1987,2019$

World Bank. (2019). Exports of goods and services (\% of GDP) - Nepal. Retrieved from World Bank: https://data.worldbank.org/indicator/NE.EXP.GNFS. ZS?locations $=\mathrm{NP}$

Yadav, P. R. (2018). Balanced Foreign Policy and National Development. The Annual Journal, 40-45.

Zirovcic, D. D. (2016). Theoretical Principles of Economic Diplomacy. Dag Hammarskjöld University College of International Relations and Diplomacy. doi:https:// dx.doi.org/10.2139/ssrn.2710671 